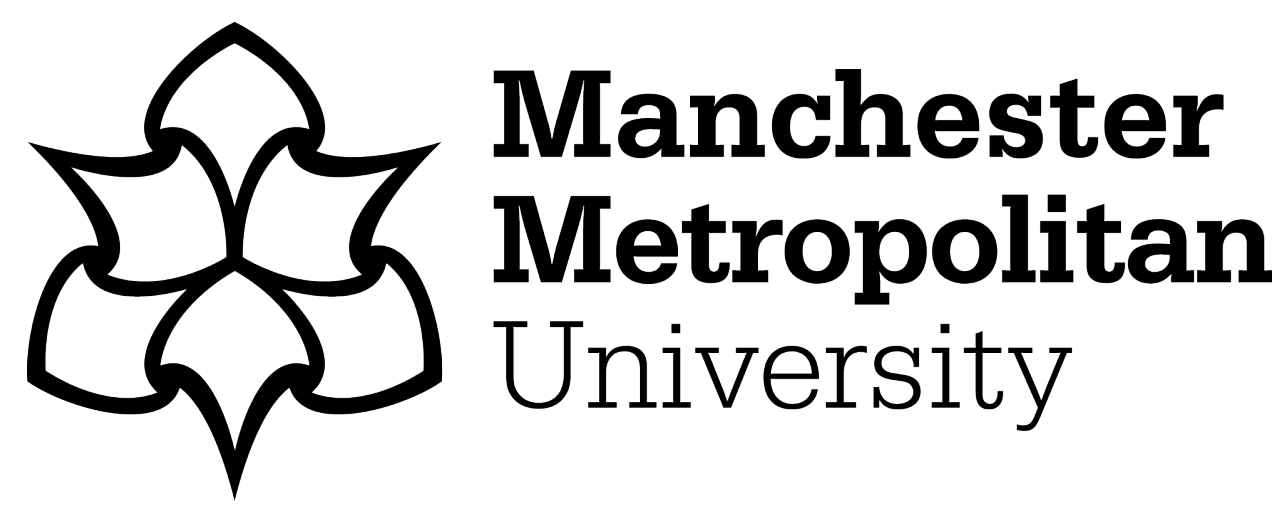

Harsanto, Budi, Kumar, Niraj, Zhan, Yuanzhu and Michaelides, Roula (2020) Responsible Research and Innovation (RRI) in Emerging Economies: a Preliminary Review. In: 2020 IEEE International Conference on Engineering, Technology and Innovation (ICE/ITMC), 15 June 2020 - 17 June 2020, Cardiff, UK.

Downloaded from: https://e-space.mmu.ac.uk/627137/

Version: Accepted Version

Publisher: IEEE

DOI: https://doi.org/10.1109/ice/itmc49519.2020.9198465

Please cite the published version 


\section{Responsible Research and Innovation (RRI) in Emerging Economies: a Preliminary Review}

\author{
Budi Harsanto \\ Management School \\ University of Liverpool, UK \\ Universitas Padjadjaran, \\ Indonesia \\ harsanto@liverpool.ac.uk
}

\author{
Niraj Kumar \\ Management School \\ University of Liverpool \\ Liverpool, United Kingdom \\ Niraj.Kumar@liverpool.ac.uk
}

\author{
Yuanzhu Zhan \\ Management School \\ University of Liverpool \\ Liverpool, United Kingdom \\ Yuanzhu.Zhan@liverpool.ac.uk
}

\author{
Roula Michaelides \\ Business School \\ Manchester Metropolitan \\ University \\ Manchester, United Kingdom \\ R.Michaelides@mmu.ac.uk
}

\begin{abstract}
Interest in responsible research and innovation (RRI) has been increased in recent years in the academic, practical and policy domains. Although initially introduced in Europe and the US, in the subsequent development, attention to RRI grows in another context. The aim of this paper is to provide a preliminary review of the current status of responsible research and innovation (RRI) research, focusing on emerging economy's context. Systematic review method is used for this purpose. The current research on RRI in emerging economies has emerged since 2013, involving multi-disciplinary researchers and has been published in journals from various disciplines. The most discussed dimension is 'inclusion' through public engagement in different phase of research and innovation. The dimension of 'anticipation' that plays an important role in the early phase of research and innovation has not been much discussed compared to other dimensions.
\end{abstract}

Keywords - responsible research and innovation, emerging economies, systematic review

\section{INTRODUCTION}

Responsible research and innovation (RRI) have recently been gaining wider attention in academic, practice, and policy [1]. RRI concern to the 'collective stewardship of science and innovation' [2]. In the past, this was related to bioethics that was developed in biomedical emerged in the 1980s; technology assessment (TA) which linked between natural science and engineering with science and policy emerged in the 1990s and responsible research of nano technology emerged in 2000s [3]-[5]. Compared to previous concepts, RRI is a broader concept by emphasising the roles and responsibilities of all stakeholders in the society involved in science development [6]. RRI has received significant attention lately regarding efforts to achieve smart and sustainable economic growth [5], [7]. The term RRI itself was first used in the 7th Framework Program EU Regulation $1291 / 2013$ which highlights the importance of cooperation between science and society [8].

RRI especially received high attention in Europe and US [5], [9]. Early concept before RRI was known as ELSA (ethical, legal, and social aspects) in Europe or ELSI (ethical, legal, and social implications) in the US [5]. In Europe, RRI became prominent with regard to the Horizon 2020 research funding from the European Commission [7]. This concept is also developing in various areas in Europe with a main orientation on the practical side that focuses on public engagement in research and innovation [10], [11]. In this way, innovation that is expected not only oriented to growth, but also to meet society needs in the form of economic, environmental, and social benefits. In this sense, the collaboration between Hard \& Science Engineering and Social Sciences and Humanities also becomes important to make the interdisciplinary effort more effective [12], [13].

In subsequent developments, this concept began to become attention outside Europe and the US considering that it was considered an 'umbrella concept' that applied across regions and contexts (Gao, Liao, Zhao). In emerging economies, with the challenge to innovate in achieving highgrowth targets as well as real problems in sustainability, RRI is considered to be relevant and even more useful to implement [14]. This paper is a preliminary review to understand the development of RRI in emerging economies. Preliminary review is commonly conducted to provide a preliminary overview on newly field in newly context [15]. This paper is structured as follows. A background of the study is given in the first section. The second section describes the basic concept of RRI that is useful for conducting analysis. Section three describes the method in a more detail. The last section explains the results and discussion.

\section{BASIC CONCEPT OF RESPONSIBLE RESEARCH AND INNOVATION (RRI)}

There are various definitions of RRI. The following is a definition of RRI offered by early scholar of RRI,

"A transparent, interactive process by which societal actors and innovators become mutually responsive to each other with a view to the (ethical) acceptability, sustainability and societal desirability of the innovation process and its marketable products (in order to allow a proper embedding of scientific and technological advances in our society) "'[10].

In the policy document, RRI is mentioned in the European Commission regulation which emphasizes the involvement of stakeholders starting from the early stage of research and innovation to meet society's concerns as well expectations, and obtain support from them for Horizon 2020 research [8]. In the academic definition, public engagement is a vital element for RRI [5].

RRI has conceptual dimensions that are helpful for understanding deeper the concept. The dimensions proposed by previous researchers vary in their nature. There is a division based on the implementation component consisting of actors, norms, and activities [16]. The European Commission mentions six dimensions, including engagement, gender 
equality, science education, ethics, open access, and governance [8]. It is found that these 2 out of six dimensions are not existent in discussions in the literature namely gender equality and science education [5]. Among the dimensions that are widely referred to are those proposed by Stilgoe et al. (2013) which consists of four dimensions: anticipation, reflexivity (sometimes referred to as public dialogue), inclusion (stakeholder engagement), and responsiveness (transparency; accessibility) [2].

Anticipation dimension refer to technical, societal, political, and environmental considerations in conducting research and innovation [2]. This consideration aims to research and innovation could give a positive impact on society as well avoid negative consequences that may arise in the future [2]. Therefore, anticipation plays a strong role in the early stage of research and innovation [11]. Reflexivity is an attitude of being aware and mindful of the limits of knowledge [2]. Reflexivity includes activities such as interdisciplinary collaboration and ethical technology assessment [2]. Inclusion refers to involve various stakeholders for collective decision making to obtain desirable outcomes [17]. Inclusion is expected to be carried out effectively so as not to waste money and time from taxpayers [18]. Responsiveness is the opposite of reactive attitude. This dimension is related to transparency in research and innovation and opening access to the public [2], [8].

\section{Methodology}

This paper uses a systematic review method in which literature is collected and systematically analysed [19]. Systematic review plays a vital role in generating knowledge through the process of searching and structured and transparent analysis to find out the development status of particular scientific fields [20]. With this process, it is expected that conclusions can be reached and reported clearly [21]. The three main steps in a systematic review are the determination of search criteria, systematic search in certain academic databases by referring to search criteria, and systematic analysis of incoming literature for later reporting [19], [21].

The search criteria in this paper are scholar literatures published in articles indexed in academic databases Scopus. The search term used is "responsible" and "research", and "innovation" in article keywords. Only articles published in peer-reviewed journals are included, while other types of publications such as working papers or thesis, or dissertations are excluded. Since this study focuses on emerging economies, only papers discussing this context are reviewed. Emerging economies refer to the list of The World Bank [22]. The criterion for the language is English only.

The search process was carried out in early 2020. After the search criteria were applied to the database, there were 233 peer-reviewed articles in English that discussed the topic of responsible research and innovation. Further, refinement feature in Scopus was used to filter out these results and find articles that match the search inclusion criteria. Refinement feature mainly used is country/ territory filters that produce 31 search results. The metadata from these articles were downloaded to allow a more detailed analysis to be carried out. Title and abstract are read manually one by one and if necessary, the full paper was downloaded and read.
The manual reading performed to ensure the relevance of the topic and context. From the manual reading, thirteen articles were excluded and seventeen were included in the review (Fig. 1). The thirteen articles were excluded because did not fit the search inclusion criteria in terms of document type (not peer-reviewed article journal), contexts (not in emerging economies setting), or language (not in English). Seventeen articles are a reasonable number for a preliminary review [15].

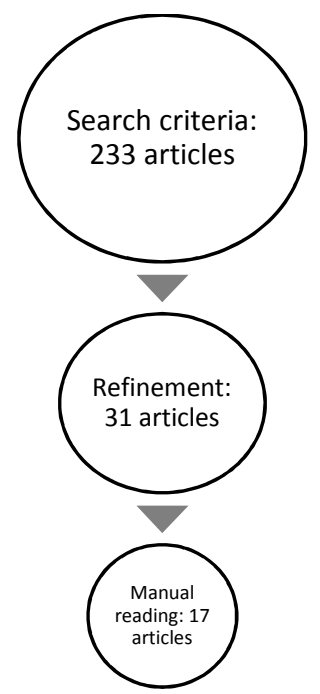

Fig. 1. Systematic search and selection process

These results were then analysed thematically to obtain insights from the paper included in the review. This analysis is known as thematic analysis in which data is coded and grouped according to certain themes [23]. Articles were coded based on both their attributes and content. The attributes analysed were publication year, journal where the article published, article word cloud, and context of the research. The results of this attribute analysis are expected to provide an overview of the development of the RRI discipline in emerging economies from year to year.

The analysis of content is conducted through coding to the articles' findings. Instead of in vivo coding, in this study we used a priori coding. In vivo coding is labeling data using terms directly taken from the data. A priori coding is labeling based on a code set that has been prepared previously. A priori coding was chosen because the RRI dimension was established in the previous literature as explained in section 2 . The four dimensions of RRI used include anticipation, reflexivity, inclusion, and responsiveness. To help the effectiveness and efficiency of the coding process, the analysis is assisted using MS Excel and NVivo 12 Pro computerassisted qualitative software analysis.

\section{RESULTS AND DISCUSSION}

Given that the RRI area is relatively new, especially for emerging economies, it is not surprising that the number of studies published is mostly in the last five years, with the highest number being 2019 (seven articles) and 2015 (five articles) (Fig. 2). The initial year of RRI publication found in this context is 2013 [24]. 
Number of articles

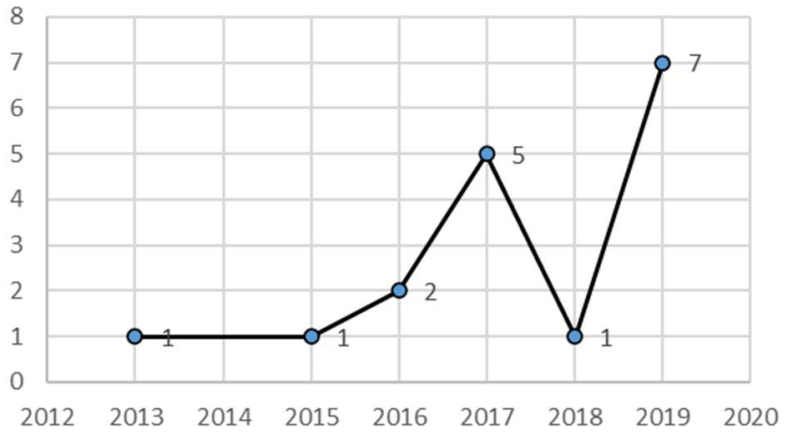

Fig. 2. Publication year

Publication outlets of the articles reviewed show the interdisciplinary nature of RRI (Table 1). Some articles are published in journals specialising in RRI such as the 'Journal of Responsible Innovation'. Some others are published in journals in specific fields such as biotechnology (e.g. 'Asian Biotechnology and Development Review'), urban planning (e.g. 'European Planning Studies'), healthcare (e.g. 'Health Research and Policy Systems'), Economy (e.g. 'Journal of Knowledge Economy'), technology (e.g. 'Technology in Society') water science (e.g. 'Water Science and Technology'), and education (e.g. 'Interactive Learning Environments').

In addition to being indeed applicable in various fields of research, this is also in harmony with two of the dimensions of RRI, namely reflexivity and inclusion, that encourages interdisciplinary collaboration across fields of science to provide maximum benefits for society.

TABLE I. PEER-REVIEWED JOURNAL

\begin{tabular}{|c|c|c|}
\hline No & Journal & $\begin{array}{c}\text { Number of } \\
\text { articles }\end{array}$ \\
\hline 1. & Journal of Responsible Innovation & 3 \\
\hline 2. & $\begin{array}{l}\text { Asian Biotechnology and Development } \\
\text { Review }\end{array}$ & 2 \\
\hline 3. & $\begin{array}{l}\text { Central European Journal of Operations } \\
\text { Research }\end{array}$ & 1 \\
\hline 4. & China and World Economy & 1 \\
\hline 5. & $\begin{array}{l}\text { DESIDOC Journal of Library and } \\
\text { Information Technology }\end{array}$ & 1 \\
\hline 6. & European Planning Studies & 1 \\
\hline 7. & Foresight and STI Governance & 1 \\
\hline 8. & Futures & 1 \\
\hline 9. & Health Research Policy and Systems & 1 \\
\hline 10. & Interactive Learning Environments & 1 \\
\hline 11. & Journal of the Knowledge Economy & 1 \\
\hline 12. & Society and Economy & 1 \\
\hline 13. & Technology in Society & 1 \\
\hline 14. & Water Science and Technology & 1 \\
\hline
\end{tabular}

Word cloud or content cloud is one of the useful ways in qualitative analysis to summaries and visualise text data [25]. One of the features in the NVivo is used to generate the most frequent words in all of the articles reviewed. Besides words 'responsible', 'research', and 'innovation' which is indeed a key term in the search process, other words that appear with high frequency are 'science' (mentioned 709 times or $0.58 \%$ of the total words used in all articles reviewed), 'development' (587 times or $0.48 \%$ ), 'technology' (417 times or $0.34 \%$ ), and 'policy' (414 times or $0.34 \%$ ).

This result is understandable because the words 'science' and 'technology' are related to research and innovation. 'Development' is related to innovation that are useful in developing knowledge as well economics. The 'policy' relates to two dimensions in RRI namely anticipation and responsiveness.

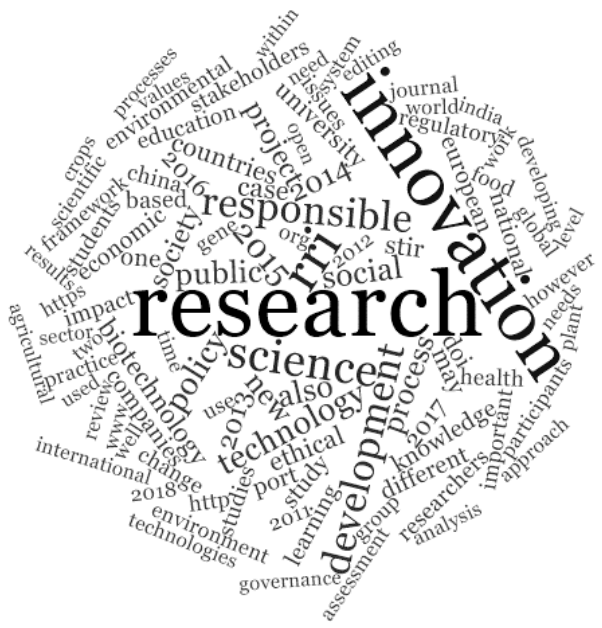

Fig. 3. Word cloud formed from articles' reviewed

The studied context varies between single and mixed contexts (Table II). The single context studied is Brazil, Chile, China, Hungary, and India. Mixed context is mixed between emerging economies (one article) or mixed with advanced economies (five articles). Most studies link their study with the RRI concept from the European Commission [8].

TABLE II. RESEARCH CONTEXT

\begin{tabular}{|l|l|c|}
\hline \multicolumn{1}{|c|}{ No } & \multicolumn{1}{|c|}{ Journal } & $\begin{array}{c}\text { Number of } \\
\text { articles }\end{array}$ \\
\hline 1. & Brazil & 3 \\
\hline 2. & Chile & 1 \\
\hline 3. & China & 2 \\
\hline 4. & Hungary & 4 \\
\hline 5. & India & 1 \\
\hline 6. & Mixed emerging & 1 \\
\hline 7. & Mixed emerging and advanced & 5 \\
\hline
\end{tabular}

When exploring into the articles' content, the most discussed dimension is inclusion (Table III). In total, nine out of seventeen articles discuss this dimension in depth. 
TABLE III. RRI IN EMERGING ECONOMIES THEMES AND REPRESENTATIVE QUOTES

\begin{tabular}{|c|c|c|c|c|c|}
\hline No & Author(s) & Anticipation & Reflexivity & Inclusion & Responsiveness \\
\hline 1. & $\begin{array}{l}\text { Barton, Román, \& } \\
\text { Rehner (2019) [26] }\end{array}$ & - & $\begin{array}{l}\text { Multidisciplinary work } \\
\text { "the continuity of } \\
\text { disciplinary and multi- } \\
\text { disciplinary work" }\end{array}$ & $\begin{array}{l}\text { Stakeholder engagement } \\
\text { "a shift towards more } \\
\text { decentralised or participatory } \\
\text { research" }\end{array}$ & - \\
\hline 2. & Das (2019) [27] & - & - & - & $\begin{array}{l}\text { Regulation } \\
\text { "Policy Statement on } \\
\text { Dissemination..." }\end{array}$ \\
\hline 3. & $\begin{array}{l}\text { Gao, Liao, \& Zhao } \\
(2019)[28]\end{array}$ & - & $\begin{array}{l}\text { Public dialogue } \\
\text { "Lacks an institutional } \\
\text { mechanism for dialogue" }\end{array}$ & - & - \\
\hline 4. & $\begin{array}{l}\text { Ligardo-Herrera, } \\
\text { Gómez-Navarro, \& } \\
\text { Gonzalez-Urango } \\
(2019)[29]\end{array}$ & - & - & $\begin{array}{l}\text { Stakeholder influence } \\
\text { "methodology to assess the } \\
\text { stakeholders' influence in a } \\
\text { research project within" }\end{array}$ & - \\
\hline 5. & $\begin{array}{l}\text { Lukovics, Udvari, } \\
\text { Nádas, \& Fisher } \\
\text { (2019) [30] }\end{array}$ & - & $\begin{array}{l}\text { Reflection } \\
\text { "Socio-Technical } \\
\text { Integration Research } \\
\text { (STIR) method, which } \\
\text { facilitates reflection" }\end{array}$ & - & - \\
\hline 6. & $\begin{array}{l}\text { Okada, Kowalski, } \\
\text { Kirner, \& Torres } \\
(2019)[31]\end{array}$ & - & - & $\begin{array}{l}\text { Stakeholder engagement } \\
\text { "to support students" } \\
\text { understanding, critical thinking } \\
\text { and engagement..." }\end{array}$ & - \\
\hline 7. & $\begin{array}{l}\text { Toarniczky, } \\
\text { Matolay, \& Gáspár } \\
\text { (2019) [32] }\end{array}$ & & $\begin{array}{l}\text { Continuous reflection } \\
\text { "create the practice for } \\
\text { continuous reflection on } \\
\text { the ongoing learning" }\end{array}$ & & $\begin{array}{l}\text { Openness and transparency } \\
\text { "does open access create } \\
\text { equality and } \\
\text { collaboration?" }\end{array}$ \\
\hline 8. & $\begin{array}{l}\text { (Adam et al., 2018) } \\
\text { [33] }\end{array}$ & $\begin{array}{l}\text { Research impact } \\
\text { assessment } \\
\text { "RIA spreading to } \\
\text { countries such as } \\
\text { Argentina..." }\end{array}$ & - & - & - \\
\hline 9. & $\begin{array}{l}\text { Inzelt \& Csonka } \\
(2017)[34]\end{array}$ & $\begin{array}{l}\text { Impact assessment } \\
\text { "environment and } \\
\text { engagement are } \\
\text { present" }\end{array}$ & $\begin{array}{l}\text { Ethics } \\
\text { "Many companies devote } \\
\text { attention to RRI-related } \\
\text { ethics..." }\end{array}$ & ( & $\begin{array}{l}\text { Open access } \\
\text { "Health and open access } \\
\text { are mentioned by a few } \\
\text { companies" }\end{array}$ \\
\hline 10. & $\begin{array}{l}\text { Lukovics \& Fisher } \\
\text { (2017) [35] }\end{array}$ & - & $\begin{array}{l}\text { Reflection } \\
\text { "showed a considerable } \\
\text { improvement in their open- } \\
\text { mindedness, their decision- } \\
\text { making awareness" }\end{array}$ & $\begin{array}{l}\text { Science integration } \\
\text { "main output of the the } \\
\text { integration of social science } \\
\text { aspects into natural science" }\end{array}$ & - \\
\hline 11. & $\begin{array}{l}\text { Lukovics, Flipse, } \\
\text { Udvari, \& Fisher } \\
\text { (2017) }\end{array}$ & - & - & $\begin{array}{l}\text { Science integration } \\
\text { "hardly understand why they } \\
\text { as natural scientists should pay } \\
\text { attention to social aspects" }\end{array}$ & $\begin{array}{l}\text { Culture } \\
\text { "STIR works differently in } \\
\text { different innovation } \\
\text { environments" }\end{array}$ \\
\hline 12. & $\begin{array}{l}\text { Monteiro, Shelley- } \\
\text { Egan, \& Dratwa } \\
(2017)[36]\end{array}$ & - & - & $\begin{array}{l}\text { Public engagement } \\
\text { "public engagement can help } \\
\text { promote greater public trust in } \\
\text { public health measures" }\end{array}$ & $\begin{array}{l}\text { Transparency } \\
\text { "transparency here } \\
\text { involves an attentiveness } \\
\text { by both public and elite } \\
\text { actors" }\end{array}$ \\
\hline 13. & $\begin{array}{l}\text { Yang \& Han (2017) } \\
{[37]}\end{array}$ & $\begin{array}{l}\text { Impact assessment } \\
\text { "discusses the } \\
\text { situations in which } \\
\text { RRI will benefit } \\
\text { economies" }\end{array}$ & - & $\begin{array}{l}\text { Stakeholder involvment } \\
\text { "Stakeholder involvement in } \\
\text { foresight and technology } \\
\text { assessment" }\end{array}$ & - \\
\hline 14. & $\begin{array}{l}\text { Chaturvedi, } \\
\text { Srinivas, \& Kumar } \\
\text { (2015) [38] }\end{array}$ & $\begin{array}{l}\text { Impact assessment } \\
\text { "socio-economic } \\
\text { assessment as part of } \\
\text { the regulatory.." }\end{array}$ & - & ( & $\begin{array}{l}\text { Transparency } \\
\text { "Enhancing transparency } \\
\text { and building a culture of } \\
\text { deliberative policy.." }\end{array}$ \\
\hline 15. & $\begin{array}{l}\text { Di Giulio, Groves, } \\
\text { Monteiro, \& Taddei } \\
\text { (2016) [39] }\end{array}$ & - & - & $\begin{array}{l}\text { Participation } \\
\text { "drawing on both 'expert' and } \\
\text { 'lay' knowledge”, }\end{array}$ & $\begin{array}{l}\text { Governance } \\
\text { call for responsiveness on } \\
\text { the part of governance } \\
\text { institutions.." }\end{array}$ \\
\hline 16. & $\begin{array}{l}\text { Ravesteijn, Liu, \& } \\
\text { Yan (2015) [40] }\end{array}$ & - & $\begin{array}{l}\text { Multi-level coordination } \\
\text { "This introduces } \\
\text { coordination problems of } \\
\text { value considerations" }\end{array}$ & $\begin{array}{l}\text { Public support } \\
\text { “..public support is crucial in } \\
\text { responsible port innovation..” }\end{array}$ & - \\
\hline 17. & $\begin{array}{l}\text { Bremer, Pakki } \\
\text { Reddy, \& Millar } \\
\text { (2013) [24] }\end{array}$ & $\begin{array}{l}\text { Vision assessment } \\
\text { "they had given little } \\
\text { thought to ethical } \\
\text { issues" }\end{array}$ & $\begin{array}{l}\text { Interdisciplinary } \\
\text { collaboration } \\
\text { "useful in nurturing inter } \\
\text { disciplinary deliberation" }\end{array}$ & - & - \\
\hline
\end{tabular}


Inclusion is an effort to open research and innovation to the public through various means. For example, through stakeholder engagement to increase participation in various phases of research and innovation [26], [31], [37]. Although stakeholders have different influences on RRI, their involvement is all needed to increase public trust in research and innovation [29], [36], [40]. Stakeholder engagement through dialogue can be done, for example, in the form of foresight and technology assessment in the early phase of research and innovation [37]. By engaging stakeholders, it is expected that collective decision making can be realised to achieve research and innovation desirable outcomes [7].

Another important thing in inclusion dimension is science integration between 'natural science', 'engineering science' and 'social science' [35], [41]. This is because sometimes researchers natural and engineering science finds it difficult to understand why they need to giving attention to the social aspects of research and innovation [41]. In the same way, it is also important to combine 'expert' and 'layman' knowledge to increase the usefulness of research and innovation for society [39]. No less important is that inclusion expected to be carried out efficiently so that it does not waste public's time and money as taxpayers [18]. The finding of inclusion as the most discussed dimension in the article reviewed is in line with the previous researchers' who found that inclusion as the dimension that representing RRI the most [5].

The next dimension that is widely discussed in the reviewed articles is reflexivity. In some respects, this dimension relates to the inclusion dimension by emphasising the importance of multidisciplinary work to facilitate researchers to reflect on the RRI [24], [26], [32]. So, it can be aligned with ethical considerations in various aspects of decision-making during research and innovation [40]. Dimension of responsiveness underlining the importance of openness and transparency for the public in accessing the results of research and innovation [32], [34]. Finally, the dimension of anticipation is the least discussed in the articles reviewed. It is related to assessment towards economic, environmental, and social impact from the research and innovation.

\section{CONCLUSION}

In this paper, we review the development of RRI in emerging economies. The analysis shows that these studies arose, especially in the last five years. Publications in this area are multidisciplinary with very diverse publication outlets from various subject areas. Interdisciplinary collaboration is highly visible in these publications. The most discussed dimension is inclusion, which is an effort to open research and innovation to the general public by different means.

This paper certainly has some limitations. As a preliminary review, the articles reviewed are limited even though refer to the literature still in a reasonable number for a preliminary review. A full-scale review is planned in the future when this field is further developed. Another way to obtain wider coverage of articles is to include other types of documents besides peer-reviewed articles, with the consequence of having to add a more stringent quality assessment in the filtering process. Future research can also be performed by using in vivo coding in the articles' findings to identify themes that are typically emerging in emerging economies that might not be found in RRI studies with advanced economies setting.

\section{ACKNOWLEDGMENT}

The first author acknowledges financial support from the Indonesia Endowment Fund for Education (LPDP) to participate at 26th ICE/ IEEE ITMC 2020 Conference in Cardiff, Wales (Virtual due to Covid-19).

\section{REFERENCES}

[1] R. Owen and M. Pansera, "Responsible Innovation and Responsible Research and Innovation," in Handbook on Science and Public Policy, no. May, 2019, pp. 26-48.

[2] J. Stilgoe, R. Owen, and P. Macnaghten, "Developing a framework for responsible innovation," Res. Policy, vol. 42, no. 9, pp. 15681580, 2013.

[3] A. Rip, "The past and future of RRI," Life Sci. Soc. Policy, vol. 10, no. 1, pp. 1-15, 2014.

[4] T. J. Silber, "Bioethics: An interdisciplinary enterprise," J. Relig. Health, vol. 21, no. 1, pp. 21-28, 1982.

[5] M. Burget, E. Bardone, and M. Pedaste, "Definitions and Conceptual Dimensions of Responsible Research and Innovation: A Literature Review," Sci. Eng. Ethics, vol. 23, no. 1, pp. 1-19, 2017.

[6] M. Schuijff and A. M. Dijkstra, Practices of Responsible Research and Innovation: A Review, no. 0123456789. Springer Netherlands, 2019.

[7] E. M. Forsberg, "ELSA and RRI - Editorial," Life Sci. Soc. Policy, vol. 11, no. 1, pp. 10-12, 2015.

[8] Official Journal of the European Union, "Regulation (EU) No 1291/2013 of the European Parliament and of the Council of 11.12.2013 establishing Horizon 2020-the Framework Programme for Research and Innovation (2014e2020) and repealing Decision No 1982/2006/EC." 2013.

[9] D. Simon, S. Kuhlmann, J. Stamm, W. Canzler, and R. Owen, "Responsible Innovation and Responsible Research and Innovation," Handb. Sci. Public Policy, no. June, pp. 26-48, 2019.

[10] R. Von Schomberg, "Prospects for Technology Assessment in a Framework of Responsible Research and Innovation," SSRN Electron. J., no. May, 2014.

[11] R. Owen, P. Macnaghten, and J. Stilgoe, "Responsible research and innovation: From science in society to science for society, with society," Sci. Public Policy, vol. 39, no. 6, pp. 751-760, 2012.

[12] L. Levidow and C. Neubauer, "EU Research Agendas: Embedding What Future?," Sci. Cult. (Lond)., vol. 23, no. 3, pp. 397-412, 2014.

[13] B. K. Myskja, R. Nydal, and A. I. Myhr, "We have never been ELSI researchers - there is no need for a post-ELSI shift," Life Sci. Soc. Policy, vol. 10, no. 1, pp. 1-17, 2014.

[14] F. Vasen, "Responsible innovation in developing countries: an enlarged agenda," in Responsible Innovation 3, Springer, 2017, pp. 93-109.

[15] C. A. Burke, "Mindfulness-based approaches with children and adolescents: A preliminary review of current research in an emergent field," J. Child Fam. Stud., vol. 19, no. 2, pp. 133-144, 2010.

[16] B. C. Stahl, "Responsible research and innovation: The role of privacy in an emerging framework," Sci. Public Policy, vol. 40, no. 6, pp. 708-716, 2013.

[17] R. Von Schomberg, "From the ethics of technology towards an ethics of knowledge policy \& knowledge assessment," 2007.

[18] B. Grimpe, M. Hartswood, and M. Jirotka, "Towards a closer dialogue between policy and practice: responsible design in HCI," in Proceedings of the SIGCHI Conference on Human Factors in Computing Systems, 2014, pp. 2965-2974.

[19] D. Tranfield, D. Denyer, and P. Smart, "Towards a methodology for developing evidence-informed management knowledge by means of systematic review," Br. J. Manag., vol. 14, pp. 207-222, 2003. 
[20] D. Denyer and D. Tranfield, "Producing a Systematic Review," The SAGE Handbook of Organizational Research Methods. pp. 671-689, 2009 .

[21] K. Govindan and M. Hasanagic, "A systematic review on drivers, barriers, and practices towards circular economy: a supply chain perspective," Int. J. Prod. Res., vol. 56, no. 1-2, pp. 278-311, 2018

[22] The World Bank Group, "Global Economic Prospects," 2017.

[23] M. Saunders, P. Lewis, and A. Thornhill, Research Methods For Business Students. Pearson, 2016.

[24] S. Bremer, G. Pakki Reddy, and K. Millar, "Bioscience and innovation research: Examining the GM animals case with Indian researchers using the Ethical Matrix," Asian Biotechnol. Dev. Rev., vol. 15 , no. 2, pp. 1-17, 2013.

[25] J. Cidell, "Content clouds as exploratory qualitative data analysis," Area, vol. 42, no. 4, pp. 514-523, 2010.

[26] J. R. Barton, Á. Román, and J. Rehner, "Responsible research and innovation (RRI) in Chile: from a neostructural productivist imperative to sustainable regional development?," Eur. Plan. Stud., vol. 27, no. 12, pp. 2510-2532, 2019.

[27] A. K. Das, "Research integrity in the context of responsible research and innovation framework," DESIDOC J. Libr. Inf. Technol., vol. 39 , no. 2, pp. 82-86, 2019.

[28] L. Gao, M. Liao, and Y. Zhao, "Exploring complexity, variety and the necessity of RRI in a developing country: the case of China," $J$. Responsible Innov., vol. 6, no. 3, pp. 368-374, 2019.

[29] I. Ligardo-Herrera, T. Gómez-Navarro, and H. Gonzalez-Urango, "Application of the ANP to the prioritization of project stakeholders in the context of responsible research and innovation," Cent. Eur. J. Oper. Res., vol. 27, no. 3, pp. 679-701, 2019.

[30] M. Lukovics, B. Udvari, N. Nádas, and E. Fisher, "Raising Awareness of Researchers-in-the-Making Toward Responsible Research and Innovation," J. Knowl. Econ., vol. 10, no. 4, pp. 15581577, 2019.

[31] A. Okada, R. P. G. Kowalski, C. Kirner, and P. L. Torres, "Factors influencing teachers' adoption of AR inquiry games to foster skills for Responsible Research and Innovation," Interact. Learn. Environ., vol. 27, no. 3, pp. 324-335, 2019.
[32] A. Toarniczky, R. Matolay, and J. Gáspár, "Responsive higher education through transformational practices - The case of a Hungarian business school," Futures, vol. 111, no. September 2018, pp. 181-193, 2019.

[33] P. Adam et al., "ISRIA statement: Ten-point guidelines for an effective process of research impact assessment," Heal. Res. Policy Syst., vol. 16, no. 1, pp. 1-16, 2018.

[34] A. Inzelt and L. Csonka, "The approach of the business sector to responsible research and innovation (RRI)," Foresight STI Gov., vol. 11, no. 4, pp. 63-73, 2017

[35] M. Lukovics and E. Fisher, "Socio-technical integration research in an Eastern European setting: Distinct features, challenges and opportunities," Soc. Econ., vol. 39, no. 4, pp. 501-528, 2017.

[36] M. Monteiro, C. Shelley-Egan, and J. Dratwa, "On irresponsibility in times of crisis: learning from the response to the Zika virus outbreak," J. Responsible Innov., vol. 4, no. 1, pp. 71-77, 2017.

[37] P. Yang and B. Han, "Responsible Research and Innovation and Its Implications for China," China World Econ., vol. 25, no. 6, pp. 120 138, 2017.

[38] S. Chaturvedi, K. R. Srinivas, and A. Kumar, "Agriculture Technology Choices and the Responsible Research and Innovation (RRI) Framework: Emerging Experiences from China and India," Asian Biotechnol, vol. 17, no. 1, pp. 93-111, 2015.

[39] G. Di Giulio, C. Groves, M. Monteiro, and R. Taddei, "Communicating through vulnerability: knowledge politics, inclusion and responsiveness in responsible research and innovation,” J. Responsible Innov., vol. 3, no. 2, pp. 92-109, 2016.

[40] W. Ravesteijn, Y. Liu, and P. Yan, "Responsible innovation in port development: The Rotterdam Maasvlakte 2 and the Dalian Dayao bay extension projects," Water Sci. Technol., vol. 72, no. 5, pp. 665677, 2015.

[41] M. Lukovics, S. M. Flipse, B. Udvari, and E. Fisher, "Responsible research and innovation in contrasting innovation environments: Socio-Technical Integration Research in Hungary and the Netherlands," Technol. Soc., vol. 51, pp. 172-182, 2017. 